E-mail: bjsir07@gmail.com

\title{
Pectin from ripe peels of mango cultivars
}

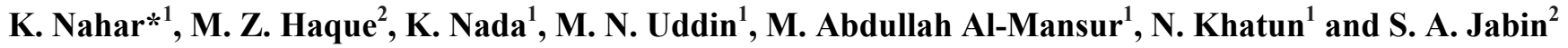 \\ ${ }^{1}$ Bangladesh Council of Scientific and Industrial Research (BCSIR) Laboratories, Dhaka. BCSIR, Dhaka-1205, Bangladesh \\ ${ }^{2}$ Institute of Food Science \& Technology (IFST), BCSIR, Dhaka-1205, Bangladesh
}

\begin{abstract}
The present study focused on the influence of different extraction conditions of pectin isolated from ripe mango peel of four Bangladeshi mango varieties (Amrapali, Fazlee, Langra \& Kharsapat). The correlation between biochemical properties and protein content were also observed. Five different extraction conditions were applied where the optimum conditions for highest yield and purity were ' $\mathrm{H}_{2} \mathrm{SO}_{4}-\left(\mathrm{NH}_{4}\right)_{2} \mathrm{SO}_{4}$ buffer $/ \mathrm{pH} 1.5 / 80{ }^{\circ} \mathrm{C} / 1 \mathrm{~h} /$ Amrapali' and 'Tem. $99.8^{\circ} \mathrm{C} / \mathrm{HCl}-\mathrm{NaOH}$ buffer/ $\mathrm{pH} 1.5 / 1 \mathrm{~h} /$ Amrapali' respectively. The best source among four varieties was Langra as it contained highest purity (AUA, $72.27 \pm 0.03 \%$ ) under a specific condition. The best extractant was $\mathrm{HCl}-\mathrm{NaOH}$ buffer as the pectin extracting with it contained minimum impurity $(3.10 \pm 0.06)$. This study also showed that pectin from Amrapali contained both Low and High Methoxyl pectin with the same extraction condition other than extractant. The proximate, elementary, microbiological, spectroscopical and structural investigations were also conducted in this study.
\end{abstract}

Keywords: Pectin; Different mango cultivars; Buffer solution; Extraction condition; Biochemical properties; Protein content

\section{Introduction}

Pectin is methylated ester and are highly heterogeneous with respect to their galacturonic acid and neutral sugar contents, their methylation and acetylation degrees, and their molar mass (Ralet and Thibault, 2002). They are widely used as gelling and stabilizing agents in food, pharmaceutical and cosmetic industries. Based on the degree of esterification (DE) it can be divided into two types: high methoxyl pectin (HM pectin) which have $\mathrm{DE}>50 \%$ and low methoxyl pectin (LM pectin) which have $\mathrm{DE}<50 \%$ (Mesbahi et al., 2005). The major raw materials used for the production of commercially acceptable pectins are citrus peel and apple pomace (May, 1990). Other sources include sugar beet residues (Yapo and Koffi, 2013), cacao husks (Theobroma cacao L.) (Nazaruddin, 2011), red dragon fruit (Hylocereus polyrhizus) (Woo et al., 2010), Kaffir Lime (citrus hustrix) (Shaha et al., 2013), chicory roots (Chicorium intybus L.) (Robert et al., 2006), mango peels (Koubala et al., 2008). However, most of these could not satisfy the industrial requirements which include high yields, best quality gels and functionality (Daniel et al., 2014). Mango peels represent about 16-19\% of the total weight of the fruit (Kansci, et al. 2003). These peels are thrown as garbage or used for animal feeding. They have been reported to be a potential source of pectins (Koubala et al.,
2008). There are nearly 100 cultivars of mango available in Bangladesh. The study have been done with four variety, named; Amrapali, Fazlee, Langra and Kharsapat. Amrapali is a hybrid variety of Dasheri and Neelum. Langra is medium size pyramidal shape light green color fruit. Kharsapat is conical shape green with red patches color and Fazlee is Pyramidal green with red patches color. The individual weight of Langra, Kharsapat and Fazlee are about 238-244g, 229-260g and 503-648g respectively (Kobra et al., 2012). In Bangladesh, 32011 hectares of land are used for the cultivation of mango with an annual production of 1047849 metric tons estimated by Bangladesh Bureau of Statistics, 2011( Barua et al., 2013). In mango processing industries, the peels are discarded as wastes.

The aim of this study was to search optimized extraction condition where the quality pectin could be isolated from different mango cultivars in Bangladesh and also to develop a suitable technology for the waste management through utilizing the byproduct from mango processing industries.

\section{Materials and methods}

Mangoes (varieties: Amrapali, Fazlee, Langra and Kharsapat) were collected from Shaheb Bazar, Rajshahi, Bangladesh.

\footnotetext{
*Corresponding author e-mail: kamrunbcsir@bcsir.gov.bd, knahar139@yahoo.com
} 


\section{Pectin extraction method}

Peels were removed from mangoes and chopped (1 sq.cm) and dried in oven at $90{ }^{\circ} \mathrm{C}$ for $6 \mathrm{~h}$ and then powdered and sieved (mesh no. 80). The moisture content was $8-10 \%$. Several extraction conditions were considered; 1) variable sources (Amrapali, Fazlee, Langra and Kharsapat)/ $\mathrm{H}_{2} \mathrm{SO}_{4}-\left(\mathrm{NH}_{4}\right)_{2} \mathrm{SO}_{4}$ buffer/ $\left.\mathrm{pH} 1.5 / 80{ }^{\circ} \mathrm{C} / 1 \mathrm{~h}, 2\right)$ variable extractants $\left(\mathrm{H}_{2} \mathrm{SO}_{4}-\left(\mathrm{NH}_{4}\right)_{2} \mathrm{SO}_{4}\right.$ buffer, $\mathrm{HCl}-\mathrm{NaOH}$ buffer and Citric acid buffer) $/ \mathrm{pH} 1.5 / 80^{\circ} \mathrm{C} / 1 \mathrm{~h} /$ Amrapali , 3) variable $\mathrm{pH}(1.5,2.0,2.5) / \mathrm{HCl}-\mathrm{NaOH}$ buffer/ $80{ }^{\circ} \mathrm{C} 1 \mathrm{~h} /$ Amrapali, 4) variable temperature $\left(80^{\circ} \mathrm{C}, 90^{\circ} \mathrm{C} \& 99.8^{\circ} \mathrm{C}\right) /$ $\mathrm{HCl}-\mathrm{NaOH}$ buffer/ pH1. / 1h/ Amrapali, 5) variable extraction time (1h, $1.3 \mathrm{~h}, 2 \mathrm{~h}, 2.3 \mathrm{~h}) / \mathrm{HCl}-\mathrm{NaOH}$ buffer/ $\mathrm{pH} 1.5 / 80^{\circ} \mathrm{C} / 1 \mathrm{~h} /$ Amrapali. In all, $25 \mathrm{~g}$ of powder was mixed with $500 \mathrm{ml}$ of extractant and processed following different extraction conditions. The extracts were filtered through a silk cloth and pectins were precipitated with double volume of methanol and dried at $60{ }^{\circ} \mathrm{C}$ in an oven for 4 hours and then powdered and stored at $25{ }^{\circ} \mathrm{C}$. The yields were 10.92-30.34\% on dry basis.

\section{Spectroscopical and structural investivation (FTIR, SEM) of Pectin}

Fourier Transform infrared analysis was carried out by ATR (Attenuated total reflection) method. The sample was scanned from 4000 to $400 \mathrm{~cm}^{-1}$ in a FTIR spectrophotometer (BRUKER, ATR crystal was germanium). The SEM micrograph of was taken by SEM (Hitachi-2600SN, Japan) by non-destructive method and the images were taken at voltage of $15.0 \mathrm{KV}$ at $68.0 \mathrm{~mm} \times 250 \mathrm{~mm}$.

\section{Biochemical properties}

Equivalent weight (Eq. wt.) was determined by Ranganna's method. About $0.5 \mathrm{~g}$ of sample was taken in a $250 \mathrm{ml}$ conical flask and $5 \mathrm{ml}$ of ethanol, $1 \mathrm{~g}$ of sodium chloride and $100 \mathrm{ml}$ of distilled water were added. Penol red or Hinton's indicator (6 drops) was added for sharpen the end point. The solution was titrated with $0.1 \mathrm{~N} \mathrm{NaOH}$. The end point was indicated by turning the yellowish color to purple color at $\mathrm{pH} 7.5$. This neutralized solution was stored for determination of Methoxyl (MeO) content. The neutral solution was collected for determination of Eq.wt. and $25 \mathrm{ml}$ of $\mathrm{NaOH}(0.25 \mathrm{~N})$ was added. The mixer was stirred thoroughly and kept at room temperature for $30 \mathrm{~min}$. After then, $25 \mathrm{ml}$ of $0.25 \mathrm{~N} \mathrm{HCl}$ was added and titrated against $0.1 \mathrm{~N} \mathrm{NaOH}$ to the same end point as before like in Eq.wt. titration. Estimation of Anhydrouronic acid (AUA) content was essential to determine the purity and DE and to evaluate the physical properties (Mohamed and Hasan, 1995). The percentage of
DE was determined on the basis of percentage of $\mathrm{MeO}$ content and percentage of AUA content (Azad et al., 2014).

\section{Proximate analysis}

Moisture and total ash content were determined using Fischer and Ranganna's method respectively. Fiber, residual fat and crude protein were determined by Fritted Glass Crucible (AOAC 978.10), Hexane Extraction (AOAC 2003.06) and Automated Kjeldahl method (AOAC 976.05) respectively.

\section{Measurement of elementary analysis}

The minerals were determined using Atomic Absorption Spectrophotometric method (AOAC, 968.08). The minerals $\mathrm{Ca}, \mathrm{Mg}, \mathrm{Fe}$ and $\mathrm{Zn}$. were measured with GBC 908 Atomic Absorption spectrophotometer. $\mathrm{P}$ was determined by the ammonium molybdate method (Shimadzu ultraviolet -visible spectrophotometer $1601 \mathrm{PC}$ ). K and Na were analyzed using a Corning 410 Flame Photometer.

\section{Microbiological analysis}

Enumeration of Total Aerobic Plate Count (Maturin and Peeler, 1998), Total Fungal Count (Tournas et al. 1998), Escherichia coli (Hitchins et al. 1998), Salmonella, (Andrews and Hammack, 1998) and Staphylococcus aureus (Bennett and Lancette, 1998) were carried out following Bacteriological Analytical Manual (1998). Total Plate Count was enumerated by Pour Plate Method on melted nutrient agar/ plate count agar. Enumeration of fungas was carried out by spread plate technique on potato dextrose agar (PDA) media. Enumeration of Pseudomonas aeruginosa and Staphylococcus aureus were carried out by selective method where BairedParker ager medium and cetrimide agar plates were used for Staphylococcus aureus and Pseudomonas aeruginosa respectively. Escherichia coli count was carried out by three-tube most probable number (MPN) method. Lactose broth and eosin methylene blue (EMB) agar were used for E. coli. Salmonella count was carried out using Enrichment method where Lactose broth, selenite broth and bismuth sulphite agar were used. Total Plate Count of Escherichia coli, Staphylococcus aureus and Fungas were enumerated on plate count agar. Incubation temperature and time were $37^{\circ} \mathrm{C}$ and $24 \mathrm{~h}$. Suspected pathogens were biochemically confirmed.

\section{Statistical analysis}

Descriptive statistics of parameters of yield\%, Eq.wt., $\mathrm{MeO} \%, \mathrm{AUA} \%, \mathrm{DE} \%$ and Protein $\%$ were computed at first. In order to test the equality of different extraction conditions, 
one way analysis of variance (ANOVA) test was used. Since parameters varies significantly $(\mathrm{p}<0.05)$ in different extraction conditions, Duncan Multiple Rank Test (DMRT) of Post Hoc was performed. SPSS of its version 17.0 was used for data analysis.

\section{Results and discussion}

\section{Structural and spectroscopical analysis}

Fig.1 shows the fingerprint of HM pectin, with a high degree of esterification. The approach was effective to confirm the pectin functional identity with esterified carboxylic groups (1744.90 cm-1) and free carboxyl groups (1642 cm-1) which were consistent with the literature of Fertonani (2006).

\section{Effect of extraction condition on pectin yield}

The yields varied from 10.76-30.43 \% (dry basis) depending on the extraction condition used. The maximum yield was $30.43 \%$ at $\mathrm{H}_{2} \mathrm{SO}_{4}-\left(\mathrm{NH}_{4}\right)_{2} \mathrm{SO}_{4}$ buffer $/ \mathrm{pH} 1.5 / 80{ }^{\circ} \mathrm{C} / 1$ hour /Amrapali. With the extraction condition: 'variable sources/ $\left(\mathrm{H}_{2} \mathrm{SO}_{4}-\left(\mathrm{NH}_{4}\right)_{2} \mathrm{SO}_{4}\right.$ buffer/ $\left.\mathrm{pH} 1.5 / 80{ }^{\circ} \mathrm{C} / 1 \mathrm{~h}\right)$ ', the yields were 30.43, 25.53, 20.62 and $17.31 \%(\mathrm{~g} / \mathrm{g})$ from Amrapali, Fazlee, Langra and Kharsapat respectively (Table I1). Yields from Fazlee and Langra were similar to the work with Améliorée and Mango mango peels where yields were 20.4 and $26.3 \%(\mathrm{~g} / \mathrm{g})$ respectively with $\mathrm{HCl}(\mathrm{pH} 1.5)$ as extractant (Koubala et al. 2008). Using $\mathrm{HCl}-\mathrm{NaOH}$ buffer instead of $\mathrm{H}_{2} \mathrm{SO}_{4}-\left(\mathrm{NH}_{4}\right)_{2} \mathrm{SO}_{4}$ buffer, the yield from Amrapali was decreased (Table $\mathrm{I}^{2}$ ). This result was consistent to (Rehman et al., 2004) where the production decreased when $\mathrm{HCl}$ used instead of $\mathrm{H}_{2} \mathrm{SO}_{4}$. Citric acid and $\mathrm{HCl}-\mathrm{NaOH}$ buffer

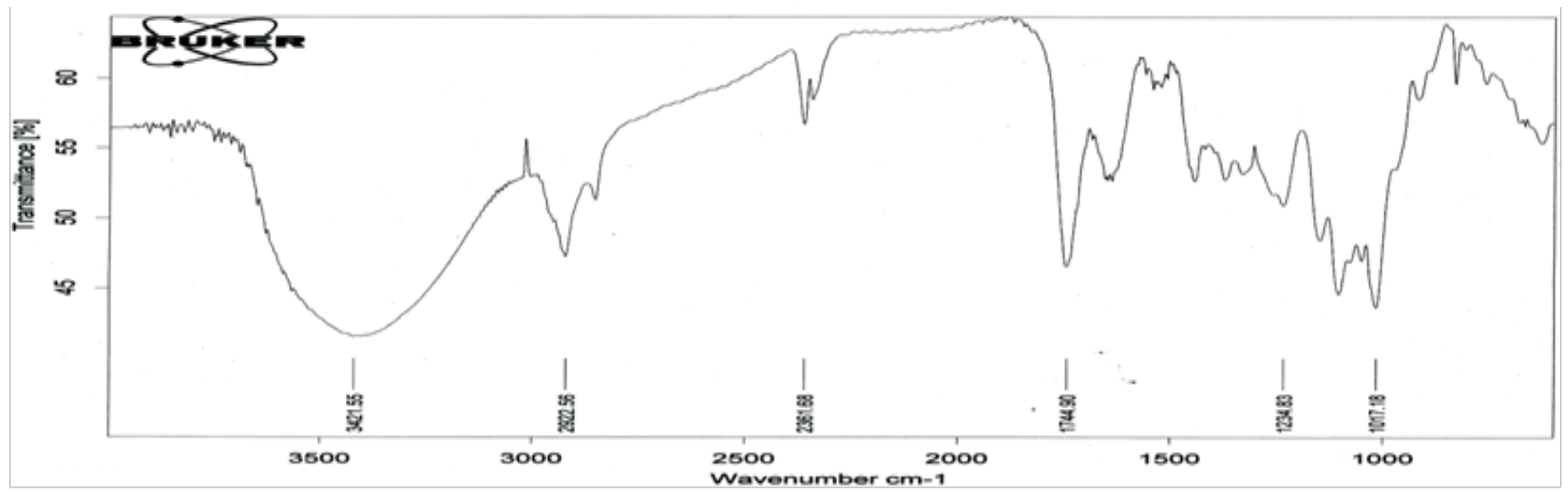

Fig. 1. FTIR analysis of pectin (Langra) (condition: $\mathrm{H}_{2} \mathrm{SO}_{4}-\left(\mathrm{NH}_{4}\right)_{2} \mathrm{SO}_{4}$ buffer $/ \mathrm{pH} 1.5 / 80{ }^{\circ} \mathrm{C} / 1 \mathrm{~h}$ )

SEM images were obtained to characterize the microstructure of pectins from Amrapali, Kharsapat \& Langra mango cultivars. The images showed the morphology of irregular particle size with rough surface textures. The images proved that pectins are amorphous. extracted almost the same amount (18.85 and $18.49 \%$ respectively) (Table $\mathrm{I}^{2}$ ) which was relevant to work of Shaha (2013). It was observed that the yield was decreased with increasing $\mathrm{pH}$ of extractant (Amrapali pectin decreased from 18.49-10.99\% with increasing $\mathrm{pH}$ of $\mathrm{HCl}-\mathrm{NaOH}$ buffer from 1.5-2.5) $\left(\right.$ Table $^{3}$ ). Low $\mathrm{pH}$ is able to promote the liberation
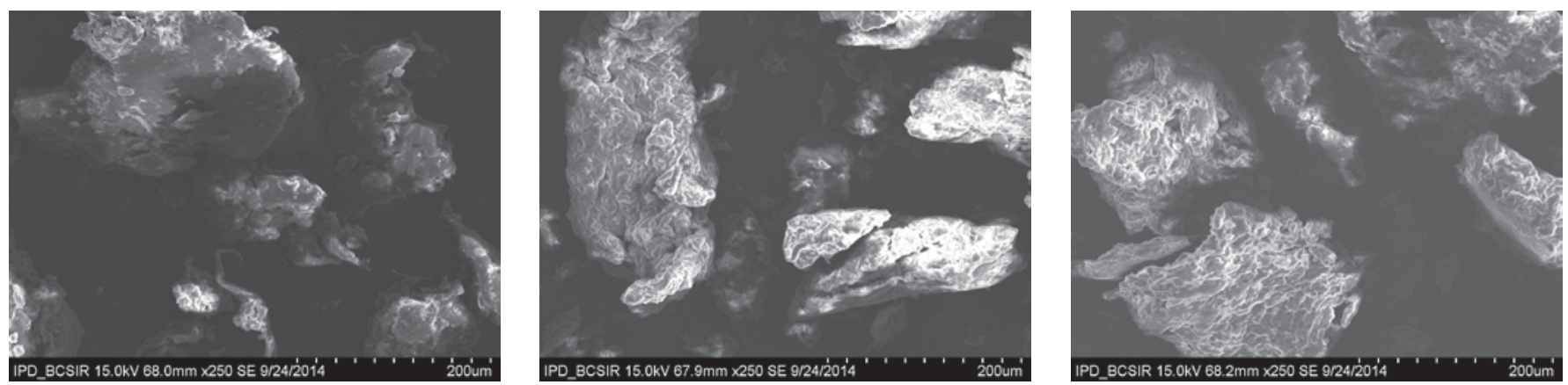

Fig. 2. SEM images of Pectins from Amrapali, Kharsapat and Langra mango cultivar respectively 
of pectin molecules from the peel during acid-washing stage because of the interaction of pectins to the hemicelluloses fractions are cleaved ( Rombouts and Thibault, 1986 ). The reduction of yield at higher $\mathrm{pH}$ might be due to some pectin is still attached to the cell wall components (Voragen, 2003). Keeping all other conditions constant other than temperature, yield was decreased from 18.49-10.76\% with increasing the heat from $80-99.8{ }^{\circ} \mathrm{C}$ for Amrapali (Table- $\mathrm{I}^{4}$ ). The cause of yield reduction at higher temperature could be attributed to break down of pectin molecules (Woo et al., 2010) and also by the depolymerisation mechanism of galacturonan chain of pectin, which is known as beta-elimination (Albersheim et al., 1960). Yields were varied with increasing extraction time. At ' $\mathrm{HCl}-\mathrm{NaOH}$ buffer/ $\mathrm{pH} 1.5 / 80^{\circ} \mathrm{C} /$ Amrapali', the yield decreased slightly with enhancing extraction time from 1-1.3 $\mathrm{h}$ but again increased after 1.3-2.3 $\mathrm{h}$. The maximum yield was $18.49 \%$ for $1 \mathrm{~h}$ and the minimum yield was 14.55 $\%$ for $1.3 \mathrm{~h}\left(\right.$ Table $\mathrm{I}^{5}$ ). Almost similar trend was observed in another study on pectin from sunflower head which demonstrated an increased yield to $10.97 \%$, whilst declined to $10.73 \%$ during extended time (Sahari et al., 2003). Pectin yield increased from 10.37-14.86\% from 30-60 min treatment at $\mathrm{pH} 3.5$, but decreased to $12.11 \%$ when treatment increased to $120 \mathrm{~min}$ (Woo et al., 2010).

\section{Effect of extraction condition on Eq.wt.}

Eq.wt. indicates whether the pectin have got partial degradation or not. In this study, it was varied from 506.58-2142 depending on the extraction condition used. The highest Eq.wt obtained 2140.70 from Amrapali (condition: ' $\mathrm{HCl}-\mathrm{NaOH}$ buffer/ $\mathrm{pH} 2.5 / 80^{\circ} \mathrm{C} / 1 \mathrm{~h}$ '). On the other hand, the lowest was 507.28 under the condition: ' $\mathrm{HCl}-\mathrm{NaOH}$ buffer/ $\mathrm{pH} 1.5 / 99.8{ }^{\circ} \mathrm{C} / 1 \mathrm{~h}$ ', this is because the partial degradation occurred at $99.8^{\circ} \mathrm{C}$. Eq.wt. of lemon pomace pectin range from 368-1632 (Azad et al., 2014), which was relevant to the result of this study. At condition: 'variable sources/ H2SO4- $\left(\mathrm{NH}_{4}\right) 2 \mathrm{SO}_{4}$ buffer/ $\mathrm{pH} 1.5 / 80{ }^{\circ} \mathrm{C} / 1 \mathrm{~h}$ ', Eq.wt. from Amrapali, Fazlee, Langra \& Kharsapat were 755.61, 795.61, 815.18 \& 686.05 respectively (Table $-\mathrm{I}^{1}$ ). In this condition, Langra contained the highest Eq.wt which was consistent to the study by (Rehman et al., 2004) and observed the Eq.wt 820 with the condition: ' $\mathrm{H}_{2} \mathrm{SO}_{4} / 1.5 / 80$ ${ }^{\circ} \mathrm{C} / 1 \mathrm{~h}$ '. By changing the extractant, e.g. using $\mathrm{HCl}-\mathrm{NaOH}$ buffer instead of $\mathrm{H}_{2} \mathrm{SO}_{4}-\left(\mathrm{NH}_{4}\right) 2 \mathrm{SO}_{4}$ buffer, Eq.wt. of Amrapali pectin did not notably decrease (from 755.61-737.51), (Table $\mathrm{I}^{2}$ ). The variation of Eq.wt. might be also dependent upon the amount of free acid (Nazaruddin, 2011). Eq.wt. was increased significantly with increasing $\mathrm{pH}$ and obtained $737.51,1871.07 \& 2142.70$ for $\mathrm{pH} 1.5,2.0$ \& 2.5 respectively (Table $\mathrm{I}^{3}$ ) with the condition: ${ }^{\mathrm{HCl}} \mathrm{HaOH}$ buffer $/ 80^{\circ} \mathrm{C} / 1 \mathrm{~h} /$ Amrapali'. The similar increasing tendency (up to $\mathrm{pH}$ 2.5) was observed in another study (Rehman et al., 2004). Eq.wt. was decreased with increasing temperature and time (Table $\mathrm{I}^{4}$ and Table $\mathrm{I}^{5}$ ) where it was observed that the highest and lowest Eq.wt. were 737.51 (at $80^{\circ} \mathrm{C}$ ) and 506.58 (at $99.8^{\circ} \mathrm{C}$ ) for $1 \mathrm{~h}$. The lower value could be for higher partial degradation of pectin (Azad et al., 2014).

\section{Effect of extraction conditions on $\mathrm{MeO}$}

$\mathrm{MeO}$ content is an important factor in controlling the setting time of pectins and the ability of pectin to form gels (Constenla and Lozano, 2003). Pectin's spreading quality and sugar binding capacity were increased with increasing $\mathrm{MeO}$ content (Madhav and Pushpalatha, 2002). $\mathrm{MeO}$ decreased with increase of sugar content with pectin (Sirisakulwat et al., 2008). In this study, the MeO content significantly varied with the variation of extraction conditions and sources. Among four varieties, $\mathrm{MeO}$ was highest for Langra $(8.94 \%)$ and the lowest for Amrapali (2.85\%) with ' $\mathrm{H}_{2} \mathrm{SO}_{4}-\left(\mathrm{NH}_{4}\right) 2 \mathrm{SO}_{4}$ buffer/ $\mathrm{pH} 1.5 / 80^{\circ} \mathrm{C} / 1 \mathrm{~h}$ ', where as Fazlee and Kharsapat contained 7.05 and $4.22 \%$ respectively (Table $\mathrm{I}^{1}$ ). The values of Fazlee and Langra were approximately similar to pectins from the peel of mango $(7.33 \%)$, banana $(7.03 \%)$ and pumelo $(8.57 \%)$ (Madhav and Pushpalatha, 2002) and the values of Amrapali \& Kharsapat were almost similar to dragon fruit pectin (2.98-4.34\%) (Ismail et al., 2012). The MeO content of orange peel pectin using citric acid and nitric acid was 5.89 and $5.58 \%$ respectively (Devi et al., 2014). Only altering the extractant e.g. using $\mathrm{HCl}-\mathrm{NaOH}$ buffer instead of $\mathrm{H}_{2} \mathrm{SO}_{4}-\left(\mathrm{NH}_{4}\right) 2 \mathrm{SO}_{4}$ buffer with constant other conditions, pectin from Amrapali contained maximum $\mathrm{MeO}$ content $(9.37 \%)$. When using citric acid buffer, it was $8.25 \%$ (Table $\left.\mathrm{I}^{2}\right)$. It was decreased with increasing $\mathrm{pH}(9.37 \%$ for $\mathrm{pH} 1.5$ and $5.51 \%$ for $\mathrm{pH} 2.5$ ) $\left(\right.$ Table $^{3}$ ). This decreasing tendency was observed to the study by (Hussain et al., 1991) who showed $\mathrm{MeO}$ content decreased from 8.35-8.13 at $\mathrm{pH}$ 2.0-4.0 respectively. Only increasing temperature (80-90 ${ }^{\circ} \mathrm{C}$ ) and time $(1-2.3 \mathrm{~h})$, the $\mathrm{MeO}$ content increased (9.37-9.59\% and 9.37-10.64\% respectively) (Table $\mathrm{I}^{4}$ and Table $\mathrm{I}^{5}$ ). It was observed that, $\mathrm{MeO}$ contents of Amrupali pectin were 9.37-10.64\% for $\mathrm{HCl}-\mathrm{NaOH}$ buffer and $8.25 \%$ for citric acid buffer. Langra pectin contained $8.94 \%$ for $\mathrm{H}_{2} \mathrm{SO}_{4}-\left(\mathrm{NH}_{4}\right)_{2} \mathrm{SO}_{4}$ buffer. According to the content of $\mathrm{MeO}$ (8.25-10.64\%), the gel grade was 200-213. This work was similar to the work of pectin from pumello, lime and mangosteen where $\mathrm{MeO}$ range was $8-11 \%$ and the gel grade was 200-213 ( Madhav and Pushpalatha, 2002). 


\section{Effect of extraction conditions on AUA}

The AUA content indicates the purity of pectin and the value of it should not be less than $65 \%$ (Food Chemicals Codex, 1996). In this study, the highest AUA content was obtained $89.10 \%$ at ' $\mathrm{HCl}-\mathrm{NaOH}$ buffer/ $\mathrm{pH} 1.5 / 99.8{ }^{\circ} \mathrm{C} /$ 1h/ Amrapali' which was the best condition on the basis of pectin's purity that was also indicated by its lowest impurity content, (protein content, $3.16 \%$ ) (Table $\mathrm{I}^{4}$ ). On the other hand, the lowest AUA content was $39.47 \%$ where protein content was highest $(52.33 \%)$ (Table $\left.{ }^{1}{ }^{1}\right)$. The AUA content of orange peel pectin was $93.28 \%$ (Devi et al., 2014) and mangosteen rind pectin was 73.16 (Madhav and Pushpalatha, 2002) respectively. With variable pectin sources at ' $\mathrm{H}_{2} \mathrm{SO}_{4}-\left(\mathrm{NH}_{4}\right) 2 \mathrm{SO}_{4}$ buffer/ $\mathrm{pH} 1.5 / 80^{\circ} \mathrm{C} / 1 \mathrm{~h}$ ', pectin from Langra, Fazlee, Kharsapat and Amrapali showed that the AUA contents were decreased gradually $(72.27,62.20,49.53$ and $39.47 \%$ respectively) whereas the protein content were increased in the same way (12.61, 14.09, 15.97 and 52.33\% respectively) (Fig: 3) where Langra showed the best source among four. Changing the extractant e.g. using $\mathrm{HCl}-\mathrm{NaOH}$ buffer with other conditions constant, the AUA content was 77.22\% and using citric acid buffer, it was $73.61 \%$ (Table $\mathrm{I}^{2}$ ). These indicated that $\mathrm{HCl}-\mathrm{NaOH}$ buffer was best according to purity. Changing the $\mathrm{pH}$ with the condition: ' $\mathrm{HCl}-\mathrm{NaOH}$ buffer/ $80^{\circ} \mathrm{C} / 1 \mathrm{~h} /$ Amrapali', the AUA content increased with decrease of $\mathrm{pH}\left(\right.$ Table $\left.\mathrm{I}^{3}\right)$. The cause of this may be degrading sugar chain from pectin polymer with increasing of hydrogen ion concentration present in the extraction medium. In this condition, the highest AUA was 77.22\% at $\mathrm{pH}$ 1.5. In another work, the AUA was 66.73-68.72\% for mango peel pectin at the same $\mathrm{pH}$ (Rehman et al., 2004). The lowest value was $39.52 \%$ at $\mathrm{pH}$ 2.5. Low AUA value indicates a high amount of protein, starch and sugars in pectins (Ismail et al., 2012). The AUA content was increased with increasing of temperature and time at 'HCl-NaOH buffer / pH 1.5 /Amrapali' (Table I ${ }^{4}$ and Table $\mathrm{I}^{5}$ respectively). Protein was denatured at $100^{\circ} \mathrm{C}$ or nearer to that temperature with prolongs heating while extracting, the purity of extracting solution might have increased. In this study, the maximum AUA content was $89.10 \%$ and the lowest protein content was 3.16 at $99.8{ }^{\circ} \mathrm{C}$ (Table $\mathrm{I}^{4}$ ). Under a constant $\mathrm{pH}$ and temperature, prolong extraction time will lead to higher pectin quality (Faravash and Ashtiani, 2008).

\section{Effect of extraction conditions on DE}

$\mathrm{DE}$ is the identification parameter for categorizing of pectins where $\mathrm{DE}>50 \%$ are known as $\mathrm{HM}$ pectins and a $\mathrm{DE}<50 \%$ are LM pectins (Walter, 1991). HM pectin forms gels under acidic conditions $(\mathrm{pH}<4.0)$ with sucrose (> $55 \%$ ) (Morris et al., 2000) whereas LM forms gels by the interaction of divalent cations, especially $\mathrm{Ca}^{2+}$, between free carboxyl groups (Cardoso et al., 2003). In this study, it was observed that pectin from Amrapali contained both HM pectin and LM pectin, because it has a wide range of DE (40.99-79.16\%), depending on the extraction condition used. When using $\mathrm{H}_{2} \mathrm{SO}_{4}-\left(\mathrm{NH}_{4}\right)_{2} \mathrm{SO}_{4}$ buffer, $\mathrm{LM}$ pectin (DE, $40.99 \%$ ) was observed, but using $\mathrm{HCl}-\mathrm{NaOH}$ buffer HM pectin (DE, 60.76-79.16\%) was noticed. The results were relevant to the values of $\mathrm{DE}$ from lemon pomace pectin where DE found 33.59-79.51\% (Azad et al, 2014). Using four varieties with the condition: ' $\mathrm{H}_{2} \mathrm{SO}_{4}-\left(\mathrm{NH}_{4}\right)_{2} \mathrm{SO}_{4}$ buffer/ $\mathrm{pH} 1.5 / 80{ }^{\circ} \mathrm{C} / 1 \mathrm{~h}$ ', the maximum DE was obtained $70.23 \%$ from Langra pectin and the minimum was $40.99 \%$ from Amrapali (Table $\mathrm{I}^{1}$ ). Pectins from Langra and Fazlee were HM pectin and from Amrapali and Kharsapat were LM pectin. But changing extractant such as using $\mathrm{HCl}-\mathrm{NaOH}$ buffer instead of $\mathrm{H}_{2} \mathrm{SO}_{4}-\left(\mathrm{NH}_{4}\right)_{2} \mathrm{SO}_{4}$ buffer, the obtained pectin from Amrapali was $\mathrm{HM}$ pectin where $\mathrm{DE}$ content was $68.89 \%$, but when used $\mathrm{H}_{2} \mathrm{SO}_{4}-\left(\mathrm{NH}_{4}\right)_{2} \mathrm{SO}_{4}$ buffer, then LM pectin (DE, $40.99 \%$ ) was obtained (Table $\mathrm{I}^{2}$ ). This result was consistent to another study where it was observed that the DE was influenced by extractant (DE ; $76 \%$ using $\mathrm{HCl}$ and $\mathrm{DE}, 73 \%$; using deionized water for Ceni mango peels) (Kratchanova et al., 1991). From the result of this study, it could be said that DE is not only depend on species, tissue, stages of maturity (Sundar Raj et al., 2012) but also depend on the extraction condition. Hence, the extraction conditions have a considerable impact on pectins' biochemical characteristics. Only changing $\mathrm{pH}$ at 'variable $\mathrm{pH} / \mathrm{HCl}-\mathrm{NaOH}$ buffer $/ 80^{\circ} \mathrm{C} / 1 \mathrm{~h} /$ Amrapali', DE increased with increasing $\mathrm{pH}$ and the result was relevant to the study by Woo et al., (2010) who found that by increasing $\mathrm{pH}$, higher $\mathrm{DE}$ was demonstrated in the pectin from red dragon fruit. In this condition, pectins with DE; $79.16 \%$ and $78.25 \%$ (at $\mathrm{pH} 2.5$ and 2.0 respectively, Table $\mathrm{I}^{3}$ ) were rapid-set pectins because it was categorized that pectins which have more than $>72 \%$ DE are rapid-set pectins and pectins which have a DE of $58-65 \%$ are slow-set pectins (Shaha et al., 2013). By keeping all other extraction conditions constant other than temperature, the DE decreased with increasing temperature (Table $\mathrm{I}^{4}$ ). Because, the high acid concentration and temperature together influence the pectin extraction and de-esterification process simultaneously. Only enhancing heat treatment from 1-2.3 h, the DEs were not significantly changed (Table $\mathrm{I}^{5}$ ) and this study was relevant to the other study of cocoa husks pectin where no significant effect of DE was observed on '1.5-3.0 h/ HCl/ $\mathrm{pH} 2.5-4.0$ ' (Chan and Choo, 2013). 
Effect of extraction conditions on protein content

In this study, the protein content significantly $(\mathrm{p}<0.05)$ varies with the variation of extractant and mango variety. In this study, the highest protein content was $(52.33 \pm 0.45 \%)$ with the extractant ' $\mathrm{H}_{2} \mathrm{SO}_{4}-\left(\mathrm{NH}_{4}\right)_{2} \mathrm{SO}_{4}$ buffer' and the lowest was
$(4.29 \pm 0.67 \%)$ for ' $\mathrm{HCl}-\mathrm{NaOH}$ buffer'. On the other hand, different $\mathrm{pHs}$, temperatures and extraction times with $\mathrm{HCl}-\mathrm{NaOH}$ buffer did not influence notably on protein content. It has been observed remarkably that protein content was decreased with increasing pectin's purity (Table I and Fig. 3).

Table I. Yield, biochemical properties (Eq.wt., MeO, AUA and DE) and protein content of extracted pectin content under different extraction conditions

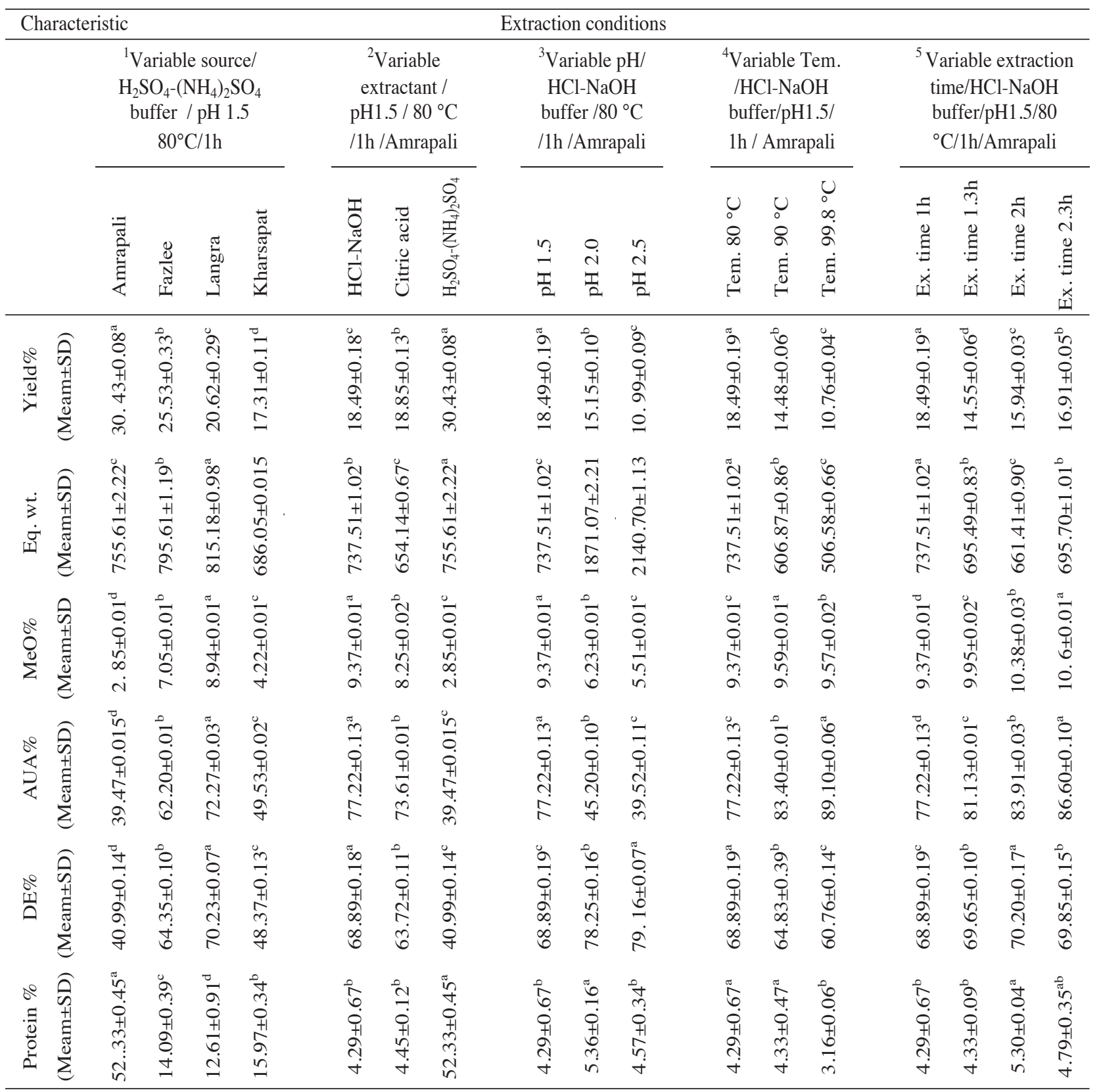

$1,2,3,4,5$ symbols indicate the different extraction conditions. Bold values indicate the maximum and minimum values in a certain condition. $($ Eq.wt. $=$ Equivalent Weight, $\mathrm{MeO}=$ Methoxyl, $\mathrm{AUA}=$ Anhydrouronic acid, DE= Degree of Esterification). a, b,c,d symbols indicate the Means containing same letters do not differ significantly at $5 \%$ level of significance. 


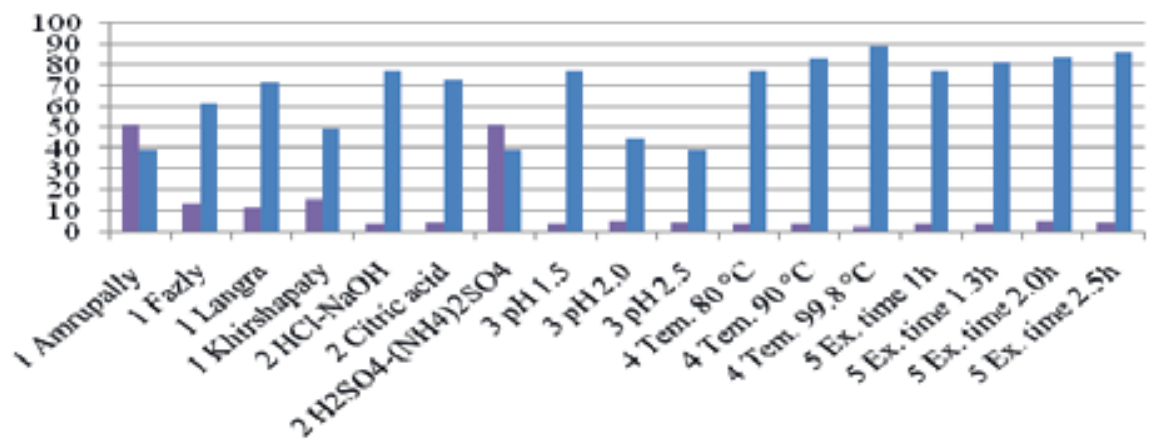

$=$ Protein content (as impuity) \%

$=\mathrm{AUA}$ (as pestin's puity)\%

Fig. 3. Pectin's purity-impurity with different extraction condition $(1,2,3,4,5$ indicate different extraction conditions)

\section{Proximate and Elementary Analysis}

The obtained moisture content was $9.4 \%$ (Table II) which is within the limit of commercial grade (9.4-11.3\%) (Devi et $a l ., 2014)$. Pectin is very hygroscopic, for this reseason, it must be preserved in closed dry atmosphere. The good quality pectin contains up to $10 \%$ ash content on the view point of gel formation (Devi et al., 2014).Therefore, isolated pectin may be considered to satisfactory good quality, supported by (Azad et at., 2014). Residual fat and crude fiber

\section{Table II. Proximate analyses of extracted pectin}

\begin{tabular}{lc}
\hline Parameters & Mixed pectin from Amrapali, Langra and Kharsapat \\
Moisture content $(\%)$ & $9.4 \pm 0.05$ \\
Total ash content $(\%)$ & $5.839 \pm 0.01$ \\
Crude fiber content $(\%)$ & Absent \\
Total fat content $(\%)$ & Negligible \\
\hline
\end{tabular}

Values are given in means of triplicate measurement

Table III. Elementary analysis of extracted pectin and comparison with reference limit (EMEA, 2008)

\begin{tabular}{|c|c|c|c|c|c|}
\hline \multirow[t]{3}{*}{ Parameters } & \multirow[t]{3}{*}{ Concentration Metals (ppm) } & \multicolumn{4}{|c|}{ Reference Concentration Limits for Individual Metal Catalysts and Metal Reagents } \\
\hline & & \multicolumn{2}{|l|}{ Oral Exposure } & \multicolumn{2}{|c|}{ Parenteral Exposure } \\
\hline & & PDE ( $\mu$ g/day) & Conc. (ppm) & PDE $(\mu \mathrm{g} /$ day $)$ & Conc. (ppm) \\
\hline $\mathrm{Na}$ & 4.248 & $\left(5.75 \times 10^{5}-3.45 \times 10^{6}\right)^{6}$ & -- & -- & -- \\
\hline $\mathrm{K}$ & 83.16 & $\left(31 \times 10^{5}\right)^{7}$ & -- & -- & -- \\
\hline $\mathrm{Ca}$ & 12.6534 & $\left(7 \times 10^{5}\right)^{8}$ & -- & -- & -- \\
\hline $\mathrm{Mg}$ & 1.6426 & $\left(15 \text { 目 } 10^{4}-5 \text { 目 } 10^{5}\right)^{9}$ & -- & -- & -- \\
\hline Mn & 0.0205 & 2500 & 250 & 250 & 25 \\
\hline $\mathrm{Fe}$ & BDL & 13000 & 1300 & 1300 & 130 \\
\hline $\mathrm{Cr}$ & 0.3874 & 300 & 30 & 30 & 3 \\
\hline $\mathrm{Ni}$ & 0.0148 & 300 & 30 & 30 & 3 \\
\hline $\mathrm{Cu}$ & 0.0668 & 2500 & 250 & 250 & 25 \\
\hline $\mathrm{Pb}$ & BDL & 100 & 10 & 10 & 1 \\
\hline $\mathrm{Cd}$ & BDL & -- & -- & -- & -- \\
\hline As & BDL & -- & $0.0008^{*}$ & -- & -- \\
\hline
\end{tabular}

$\mathrm{BDL}=$ Bellow detection limit $(\mathrm{As}=1.0 \mathrm{ppb}, \mathrm{Cd}=0.03 \mathrm{ppm}, \mathrm{Pb}=0.10 \mathrm{ppm}, \mathrm{Fe}=0.30 \mathrm{ppm}) . \mathrm{PDE}=$ permitted daily exposure limit. 6 indicate that, the acceptable range of sodium intake for adults according to (European Food Safety Authority, 2006).

7 indicate the average dietary intake of potassium according to (European Food Safety Authority, 2009).

8 indicate that acceptable range of calcium intake for adults according to (European Food Safety Authority, 2009).

9 indicate that acceptable range of magnesium intake according to (European Food Safety Authority, 2009).

*indicate that acceptable range of As. 
was also observed negligible amount. From the analysis it has been shown (Table III) that the heavy metals like As, Cd, $\mathrm{Fe}$ and $\mathrm{Pb}$ were in below the detection limit (BDL) and $\mathrm{Cr}(0.3874 \mathrm{ppm}), \mathrm{Ni}(0.0148 \mathrm{ppm})$ and $\mathrm{Cu}(0.0668 \mathrm{ppm})$ were in acceptable limit comparing with given reference data (Table III) . On the other hand, the nutrient inorganic components like $\mathrm{Na}, \mathrm{K}, \mathrm{Ca}, \mathrm{Mn}$ and $\mathrm{Mg}$ are shown in acceptable limit.

\section{Microbiological analysis}

Microbiological test clearly indicated that the product is microbiologically acceptable up to 6 months compared with 'Recommended Microbial Limit (U.S. Pharmacopia)' (Table IV).
Bangladeshi mango varieties can be considered as the sources of pectin for commercial production along with other sources.

\section{Acknowledgements}

The authors would like to thank Bangladesh Council of Scientific and Industrial Research Laboratories, Dhaka for providing the facilities to accomplish this research work successfully.

Table IV. Microbial shelf-life studies of extracted pectin and microbial Limit (U.S. Pharmacopia)

\begin{tabular}{|c|c|c|c|}
\hline Parameters & $\begin{array}{l}\text { Extracted } \\
\text { Pectin }\end{array}$ & $\begin{array}{l}\text { Pectin (6 } \\
\text { months after } \\
\text { preparation) }\end{array}$ & $\begin{array}{l}\text { Recommended (from U.S. } \\
\text { Pharmacopeia) (cfu/g or mL) }\end{array}$ \\
\hline Total Aerobic Microbial Count NMT, (cfu/g) & $<10$ & 35 & $10^{4}$ \\
\hline E. coli, in $10 \mathrm{~g},(\mathrm{cfu} / \mathrm{g})$ & Absent & Absent & Absence \\
\hline Staphylococcus aureus in $1 \mathrm{~g},(\mathrm{cfu} / \mathrm{g})$ & Absent & Absent & --- \\
\hline Salmonella spp. in $10 \mathrm{~g},(\mathrm{cfu} / \mathrm{g})$ & Absent & Absent & Absence \\
\hline $\begin{array}{l}\text { Total combined Yeast and Mold count } \\
\mathrm{NMT},(\mathrm{cfu} / \mathrm{g})\end{array}$ & Absent & Absent & $10^{3}$ \\
\hline
\end{tabular}

NMT $=$ Not more than

\section{Conclusion}

The optimum condition identified for highest purity (AUA; $89.10 \pm 0.06 \%$ ) and lowest impurity (protein content; $3.10 \pm 0.06 \%$ ) is “Tem. $99.8^{\circ} \mathrm{C} / \mathrm{HCl}-\mathrm{NaOH} / \mathrm{pH} 1.5 / 1 \mathrm{~h}$ " for Amrapali. The condition for highest yield $(30.43 \pm 0.08 \%)$ is " $\mathrm{H}_{2} \mathrm{SO}_{4}-\left(\mathrm{NH}_{4}\right)_{2} \mathrm{SO}_{4} / \mathrm{pH} \quad 1.5 / 80{ }^{\circ} \mathrm{C} / 1 \mathrm{~h} /$ Amrapali". A correlation between AUA and protein content (fig: 3) was observed sharply in this study. Langra is the best source among four as its pectin contain highest purity (AUA, $72.27 \pm 0.03 \%)$ and lowest protein content (12.61 \pm 0.91$)$ with the condition of "variable source/ $\mathrm{H}_{2} \mathrm{SO}_{4}-\left(\mathrm{NH}_{4}\right)_{2} \mathrm{SO}_{4} / \mathrm{pH} 1.5$ $80^{\circ} \mathrm{C} / 1 \mathrm{~h}$ ". Two kinds of pectin (HM and LM) were observed; HM pectin from Langra and Fazlee and LM pectins from Amrapali and Kharsapat. It was also noticed that both HM and LM pectins were obtained from Amrapali only for the change of extractants. Using $\mathrm{HCl}-\mathrm{NaOH}$ for Amrapali pectin, the highest Eq.wt. was $2140.70 \pm 1.13$ at $\mathrm{pH} 2.5$ and the

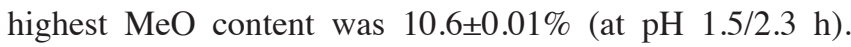
From this investigation, it can be concluded that a suitable extraction procedure for high yield and high quality pectin from Bangladeshi mango varieties was established. Thus,

\section{References}

Albersheim P, Neukom H and Deuel H (1960), Splitting of pectin chain molecules in neutral solutions, Arch Biochem Biophys. 90: 46-51.

Andrews WH and Hammack TS (1998), Bacteriological Analytical Manual, $8^{\text {th }}$ Ed., Chapter 5 (Salmonella).

AOAC (2005), Official Methods of Analysis of AOAC International, $18^{\text {th }}$ Ed., Association of Official Analytical Chemists, Gaithersberg, MD, USA, Official method (978.10), (2003.06), (976.05), (968.08).

Azad AKM , Ali MA, Aktar MS, Rahman MJ and Ahmed M (2014), Isolation and Characterization of Pectin Extracted from Lemon Pomace during Ripening, Journal of Food and Nutrition Sciences 2: 30-35.

Barua H, Patwary MMA and Rahman MH (2013), Performance of BARI mango (Mangifera indica L.) varieties in Chitagong region, Bangladesh j. Agril. 38: 203-209. 
Bennett RW and Lancette GA (1998), Bacteriological Analytical Manual, $8^{\text {th }}$ Ed., Revision A, Chapter 12 (Staphylococcus aureus).

Cardoso SM, Coimbra MA and Lopes da Silva JA (2003), Temperature dependence of the formation and melting of pectin-Ca2+ networks: a rheological study, Food Hydrocolloid. 17: 801-807.

Chan SY and Choo WS (2013), Effect of extraction conditions on the yield and chemical properties of pectin from cocoa husks, Food Chem. 141: 3752-3758.

Constenla D and Lozano JE (2003), Kinetic model of pectin demethylation, Latin Am Appl Res. 33: 91-95.

Devi WE, Shukla RN, Abraham A, Jarpula S and Kaushik U (2014), Optimized Extraction Condition and Characterization o f Pectin from Orange Peel, IJREAT. 2: 1-9.

Daniel, Ikenna Udenwobele (2014), Extraction, Partial Purification and Characterization of Pectinases Isolated from Aspergillus Species Cultured on Mango (Mangifera Indica) Peels, African Journal of Biotechnology 13(24): 2445-54.

EMEA (2008), Guideline on the Specification Limits for Residues of Metal Catalysts or Metal Reagents, Emea/Chmp/Swp/4446/2000, (January), 1-34.

European Food Safety Authority (2006), Tolerable Upper Intake Levels Scientific Committee on Food Scientific Panel on Dietetic Products, Nutrition and Allergies.

European Food Safety Authority (2009), Chromium ( III ), iron ( II ) and selenium-humic acid / fulvic acid chelate and supplemented humifulvate added for nutritional purposes to food Scientific Opinion of the Panel on Food Additives and Nutrient Sources added to Food (Questions No EFSA-Q, 1147, 1-36).

Faravash RS and Ashtiani FZ (2008), The influence of acid volume, ethanol-to-extract ratio and acid-washing time on the yield of pectic substances extraction from peach pomace, Food Hydrocolloid. 22: 196-202.

Fertonani HCR, Scabio A, Canteri MH, Carneiro EBB, Nogueira A and Wosiacki G (2006), Influence of acid concentration on extraction and quality of apple pomace pectin, Semin-Ciências Agrár Londrina 27: 599-612.
Food Chemical Codex (1996), $4^{\text {th }}$ Ed., National Academy Press, Washington D.C.

Hitchins AD, Feng P, Watkins WD, Rippey SR and Chandler LA (1998), Bacteriological Analytical Manual, $8^{\text {th }}$ Edition, Revision A, Chapter 4 (Escherichia coli and the Coliform Bacteria).

Hussain T, Baig MQ and Haroon R (1991), Extraction and evaluation of pectin from mango peel, Pakistan J Agric Res. 12: 213 - 216.

Ismail NSM, Ramli N, Hani NM and Meon Z (2012), Extraction and characterization of pectin from dragon fruit (Hylocereus polyrhizus) using various extraction conditions, Sains Malays. 41: 41-45.

Kansci G, Koubala BB and Lape IM (2003), Effect of ripening on the composition and the suitability for jam processing of different varieties of mango (Mangifera indica), Afr j Biotechnol. 2: 301-306.

Kobra K, Hossain MA, Talukder MAH and Bhuyan MAJ (2012), Performance of twelve mango cultivars grown in different agro-ecological zones of Bangladesh, Bangladesh J. Agril. Res. 37: 691-710.

Koubala BB, Kansci G, Mbome LI, Crépeau MJ, Thibault JF and Ralet MC (2008), Effect of extraction conditions on some physicochemical characteristics of pectins from "Améliorée" and "Mango" mango peels, Food Hydrocolloid 22: 1345-1351.

Kratchanova M, Benemou C and Kratchanov C (1991), On the pectic substances of mango fruits, Carbohyd Polym. 15: 271-282.

Madhav A and Pushpalatha PB (2002), Characterization of Pectin Extracted From Different Fruit Wastes, Journal of Tropical Agriculture 40: 53-55.

Maturin LJ and Peeler JT (1998), Bacteriological Analytical Manual, 8th Ed., Revision A, Chapter 3 (Aerobic Plate Count).

Mohamed S and Hasan Z (1995), Extraction and characterisation of pectin from various tropical agrowastes, AFJ. 10: 143-150.

Mesbahi G, Jamalian J and Farahnaky A (2005), A comparative study on functional properties of beet and citrus pectins in food systems, Food Hydrocolloid. 19: 731-738. 
Morris GA, Foster TJ and Harding SE (2000), The effect of the degree of esterification on the hydrodynamic properties of citrus pectin, Food Hydrocolloid 14: $227-235$.

May CD (1990), Industrial pectins:Sources, production and applications, Carbohyd Polym. 12: 79-99.

Nazaruddin R (2011), Effect of ammonium oxalate and acetic acid at several extraction time and $\mathrm{pH}$ on some physicochemical properties of pectin from cocoa husks (Theobroma cacao), African Journal of Food Scienc. 5: 790-798.

Toxicological Review (2010), Review Literature And Arts Of The Americas 39(110): 759-786.

Ralet MC and Thibault JF (2002), Interchain heterogeneity of enzymatically deesterified lime pectins, Biomacromolecules 3: 917-925.

Rehman Z, Salariya A, Habib F and Shah WH (2004), Utilization of Mango peels as a source of Pectin, Jour. Chem. Soc. Pak. 26: 73-76.

Robert C, Devillers T, Wathelet B, Van Herck JC and Paquot M (2006), Use of a Plackett-Burman experimental design to examine the impact of extraction parameters on yields and compositions of pectins extracted from chicory roots (Chicorium intybus L.), J Agric Food Chem. 54: 7167-7174.

Rombouts FM and Thibault JF (1986), Feruloylated pectic substances from sugar-beet pulp, Carbohyd Res. 154: $177-187$.

Sahari MA, Akbarian MA and Hamedi M (2003), Effect of variety and acid washing method on extraction yield and quality of sunflower head pectin, Food Chem. 83: 43-47.

Shaha RK, Punichelvana YNAP and Afandi A (2013), Optimized Extraction Condition and Characterization of Pectin from Kaffir Lime ( Citrus hystrix ), Res $J$ Agriculture \& Forestry Sci. 1: 1-11.

Sirisakulwat S, Nagel A, Sruamsiri P, Carle R and Neidhart $S$ (2008), Yield and quality of pectins extractable from the peels of Thai mango cultivars depending on fruit ripeness, J Agric Food Chem. 56: 10727-10738.
Sundar Raj AA, Rubila S, Jayabalan R and Ranganathan TV (2012), A review on pectin: Chemistry due to general properties of pectin and pharmaceutical uses, Scientific reports 1(2): 1-4.

Tournas V, Stack ME, Mislivec PB, Koch HA and Bandler R (1998), Bacteriological Analytical Manual, 8th Ed., Revision A, Chapter 18 (Yeasts, Molds and Mycotoxins).

Voragen ACJ, Rolin C and Marr BU (2003), Pectins In: Polysaccharides, Ed., Voragen ACJ, Rolin C, Marr BU, Challen I, Riad A and Lebabar R, Wiley-VCH., New York, pp 189-195.

Walter RH (1991), The chemistry and technology of pectin, Food Science and Technology-A series of monographs, Academic Press, New York.

Woo K, Chong YY, Li Hiong SK and Tang PY (2010), Pectin Extraction and Characterization from Red dragon Fruit (Hylocerus polyrhyzuz): A Preliminary Study, J Biol Sci. 10: 631-636.

Yapo B and Koffi K (2013), Extraction and Characterization of Highly Gelling Low Methoxy Pectin from Cashew Apple Pomace, Foods 3: 1-12.

Received: 20 July 2016; Revised: 30 January 2017;

Accepted: 29 May 2017. 